Revue Française de Civilisation Britannique

\title{
Community Energy in the United Kingdom:beyond or between the Market and the State?
}

L'énergie coopérative au Royaume-Uni: quelle place par rapport au marché et à l'État?

\section{Pierre Wokuri}

\section{OpenEdition}

\section{Journals}

Electronic version

URL: https://journals.openedition.org/rfcb/7976

DOI: $10.4000 /$ rfcb.7976

ISSN: 2429-4373

\section{Publisher}

CRECIB - Centre de recherche et d'études en civilisation britannique

\section{Electronic reference}

Pierre Wokuri, "Community Energy in the United Kingdom:beyond or between the Market and the State?", Revue Française de Civilisation Britannique [Online], XXVI-2 | 2021, Online since 05 January 2021, connection on 05 January 2022. URL: http://journals.openedition.org/rfcb/7976 ; DOI: https:// doi.org/10.4000/rfcb.7976

This text was automatically generated on 5 January 2022.

\section{c)}

Revue française de civilisation britannique est mis à disposition selon les termes de la licence Creative Commons Attribution - Pas d'Utilisation Commerciale - Pas de Modification 4.0 International. 


\section{Community Energy in the United Kingdom:beyond or between the Market and the State?}

L'énergie coopérative au Royaume-Uni: quelle place par rapport au marché et à l'État?

Pierre Wokuri

\section{Introduction}

I do not see the government's task as being to try and plan the future shape of energy production and consumption. It is not even primarily to try to balance UK demand and supply for energy. Our task is rather to set a framework which will ensure that the market operates in the energy sector with a minimum of distortion and energy is produced and consumed efficiently.

(Nigel Lawson, Secretary of State for Energy, Cambridge, 28 June 1982)

Delivered by the then Secretary of State for Energy in the United Kingdom, this speech introduces one of the key characteristics of the British energy policy from the 1980s until the mid-2000s: the hegemony of a "pro-market energy policy paradigm", or PEPP (Kern, Kuzemko and Mitchell, 2014: 516). Through the latter, "energy was understood as a 'normal' tradable commodity and the market was seen as the most efficient vehicle for energy supply. The role of the state was simply to create and maintain a level playing field open to competitive forces, by establishing and enforcing fair market rules. (...) In terms of the goals of energy policy the PEPP's principal aim was to establish and maintain a competitive, freely trading energy market" (Kern, Kuzemko and Mitchell, 2014: 516). This interpretive framework fitted well within the overall approach of less State involvement in the economy that had dominated elite UK circles since the 1980s (Kern, Kuzemko and Mitchell, 2014: 516) and shows the embeddedness of energy policies within UK's 'liberal market economy' (Hall and Soskice, 2001). In this macro context, the British energy policy regime is depicted as large-scale, centrally-planned and private-sector led sector with limited citizen involvement in energy planning and development (Walker et al, 
2007), and with successive systems of market support for renewable energy that have been more effectively exploited by large, incumbent energy businesses, rather than smaller, new entrants (Strachan et al, 2015).

However, since 2000, a new theme has emerged in both the policy discourse and the investment of public resources around the concept of community renewable energy development with notions of community-led, controlled and owned development of renewable energy installations (Walker et al, 2006). From five in 2010 to 157 in 2019, the number of electricity generation projects owned by community groups has risen dramatically (Community Energy England, State of the Sector Report, 2019). The emergence of this type of initiative raises a key question: does community energy represent an alternative model beyond the market and the State? This interrogation is related to a broad range of issues regarding public services generally and electricity in particular, especially the democratisation of these services with greater participation by the general public in management processes and the role of the State in the emergence of new economic models within markets. By examining the former, this article takes stock of the contribution of community energy to a process of energy democracy with decentralised energy provision, collective forms of ownership of energy and energy sovereignty over resources (Becker and Naumann, 2017: 5).

3 To think over whether community represents an alternative model beyond the market and the State, this article draws on a research design structured around three levels of analysis: 1) a micro level looking at specific community energy initiatives on the ground; 2) a meso level looking at the collective organisations and networks supporting such initiatives in the United Kingdom; and 3) a macro level looking at the interplays between community energy projects and the British policy regime.

4 To analyse the micro level, I used a similar approach to the advanced preparation fieldwork (APF) developed by Boudet and McAdam in their work on the opposition to energy projects in the United States. This method includes semi-structured interviews with key actors of local energy projects and has been mobilised to study three community energy organisations (table 1 ).

Table 1: Case studies analysed in the article.

\begin{tabular}{|l|l|l|}
\hline Name & Starting year & Technology \\
\hline Meadows Ozone Energy Services (MOZES) & 2009 & Photovoltaic \\
\hline Bristol Energy Cooperative (BEC) & 2011 & Photovoltaic \\
\hline South East London Community Energy (SELCE) & 2014 & Photovoltaic \\
\hline
\end{tabular}

5 The meso level has been analysed by looking at the framwork (Snow et al, 2019) developed by the collective organisations and networks supporting community energy in the United Kingdom. To do this, I specifically focus on the political work (Smith, 2019) developed by these organisations to influence and change energy policies.

6 To capture the macro level, the policy regime approach developed by Michael Howlett ${ }^{1}$ has been the starting point to build a specific theoretical tool in line with community 
energy issues at the macro level (for a detailed presentation of this approach on community energy in Denmark and France see Wokuri, 2019).

7 To set out whether community represents an alternative model beyond the market and the State, this article is organised in two sections. In the first section, I show that community energy in the United Kingdom constitutes an alternative model to market and State arrangements with the opening of three possibilities: ownership with energy infrastructures owned by local community groups, participation with higher level of citizen involvement and economic benefits with profits made from electricity generation distributed within local areas. In the second section, I will show that the transformative power of this model is limited because community energy is embedded between the State and the market. I will show that this embeddedness is characterised by the fact that community energy organisations struggle to institutionalise advantages and to challenge decisions that affect them negatively, and by a corrective role with a provision of services (e.g. fuel poverty alleviation) that was previously assured by State and market actors.

The data used in this article stems from semi-structured interviews with key actors (e.g. citizens involved in organisations developing renewable energy projects), participant observation (e.g. meetings of networks supporting community energy groups) and an extensive content analysis of policy documents (e.g. public hearing transcripts).

\title{
Community Energy in the United Kingdom: an Alternative Model to Market and State Arrangements
}

\begin{abstract}
What makes us different from a typical commercial enterprise? Our co-operative model democratises energy ownership. There is one-member-one-vote irrespective of shareholding, and a strong participatory ethos. As a member you will have an equal say in the strategic development of BEC through general meetings, and you can get further involved through joining working groups and standing for election to the Board (...) Our rules forbid the sale of our assets to commercial organisations should BEC be wound up, and we are bound by them to act for the benefit of the community. We do this in a number of practical ways: Our existing and future solar installations help communities reduce their energy bills and use green energy, thereby cutting carbon emissions. We promote the benefits of community energy and $100 \%$ renewable energy. We run an energy-switching scheme, produce regular newsletters, and provide volunteering opportunities (...) We contribute revenue from our projects to a community benefit fund.

(Bristol Energy Cooperative Community Share Offer No. 3 Phase 2 2015: 5).
\end{abstract}

9 This extract from a share offer document written by the Bristol Energy Cooperative (BEC) highlights that renewable energy cooperatives present a certain degree of hybridity because they "simultaneously engage in activities typically performed by three distinct organisational forms - community groups, environmental NGOs and corporations" (Huybrechts and Haugh, 2017: 8).

Citizen mobilisation, environmental activism and income generation from energy production, activities usually carried out by three separate organisations, are brought together by community energy organisations like BEC (table 2). This combination is critical to understanding the alternative dimension of community energy organisations. They borrow from community groups by emphasizing local political 
participation but they also borrow from green NGOs and from corporations by supporting renewable energy and by looking for income generation related to energy generation.

Table 2: Community energy organisations as hybrid organisations: evidence from Bristol Energy Cooperative

\begin{tabular}{|l|l|}
\hline Activities & Examples from BEC \\
\hline $\begin{array}{l}\text { Citizen } \\
\text { mobilisation }\end{array}$ & $\begin{array}{l}\text { "1. Support the work of community organisations Coexist in Hamilton House and Knowle } \\
\text { our decisions about where surplus money goes and which projects to support in Bristol - } \\
\text { each member gets one vote." (Bristol Energy Cooperative blog, Seven reasons to } \\
\text { become a member of Bristol Energy Cooperative, 15 May 2012) }\end{array}$ \\
\hline $\begin{array}{l}\text { Environmental } \\
\text { activism }\end{array}$ & $\begin{array}{l}\text { Cooperative incentivising its members to switch to a green energy supplier, } \\
\text { lobbying members of the House of Commons to support wind power and the } \\
\text { feed-in-tariff for renewable energy generation, involved in a mobilisation } \\
\text { against a Coal Bed Methane project (Insights from interviews) }\end{array}$ \\
\hline $\begin{array}{l}\text { Energy } \\
\text { generation }\end{array}$ & $\begin{array}{l}\text { Owner of rooftop solar installations on 12 community buildings across the Bristol } \\
\text { region and two ground-mounted solar farms - one in Lawrence Weston in Bristol } \\
\text { and one in Somerset (BEC website) }\end{array}$ \\
\hline
\end{tabular}

11 When it comes to income generation, a key element makes community energy organisations different from conventional energy companies: the use of community share offers to raise investment for project development. Five of their characteristics make them different from a traditional investment in a private company: 1) shares can go down in value, but they cannot increase in value above their original price which prevents any speculation dynamics; 2) any shareholder has one vote regardless of the number of shares owned, while a majority stakeholder can make all the decisions in a private company; 3) the dividends paid on every share are capped $-4 \%$ in the case of $\mathrm{BEC} ; 4)$ there are limits on individual shareholdings, $£ 20,000$ in the case of BEC ; and 5) the sale of shares is protected by an asset lock (mentioned in the previous extract).

In addition to the hybridity mentioned above, the extract from the share offer also introduces the three dimensions that make community energy different from commercial and market arrangements: 1) ownership; 2) participation; and 3) economic benefits.

\section{Community energy as a tool for the democratisation of public services through collective ownership}

13 A first difference between community energy groups and commercial companies, public utilities lies in the ownership organisation. When it comes to renewable energy implementation, the community approach has been distinguished from public utility and private supplier approaches in terms of ownership. Through the second approach, the technology and energy infrastructures are owned by the State with economic benefits returned to public authorities while through the third approach ownership is private with differentiated returns to financial investors (Walker and Cass, 2007: 
461-462). With a community approach, the technology and energy infrastructures are collectively owned through cooperative-based share ownership or partnership arrangements between a local authority and/or community institutions (Walker and Cass, 2007: 461-462). With this ownership organisation, community energy helps to democratise public services by opening two dimensions within energy projects: " $a$ process dimension, concerned with whom a project is developed and run by, who is involved and has influence (...) an outcome dimension concerned with how the outcomes of a project are spatially and socially distributed - in other words, who the project is for; who it is that benefits particularly in economic or social terms" (Walker and Devine-Wright, 2008: 498). This collective form of ownership prevails in BEC with around 600 shareholders owning different photovoltaic generation sites with a total capacity of $9 \mathrm{Mw}$. To become a shareholder, the minimum to invest is $£ 50$ with a maximum of $£ 100,000$ with a return of $5 \%$ on the investment. The collective dimension of ownership is protected by the legal structure used by community energy groups to formalise their existence with most of them having an "asset lock" clause which prevents them from selling the infrastructures to a commercial organisation (Braunholtz-Speight et al, 2018).

This form of ownership is one the key characteristics of community energy and is connected to criticisms of the market concentration of electricity supply in the United Kingdom. As in other national contexts, "dissatisfaction with the outcomes of previous privatisations spurs demands for collective ownership" (Becker and Naumann, 2017: 7) and fuels the motivation to develop community energy projects. This connection, which exists in other markets, between dissatisfaction with market domination by big corporations and the development of initiatives willing to collectively own market shares prevails in the frameworks proposed by community energy actors in the United Kingdom (Snow et al, 2019). ${ }^{2}$ According to them, the role and power of large corporations, in particular the Big $\mathrm{Six}^{3}$ is a major problem that community energy can tackle (Table 3).

Table 3: Community energy as a solution to tackle the "corporation hegemony problem"

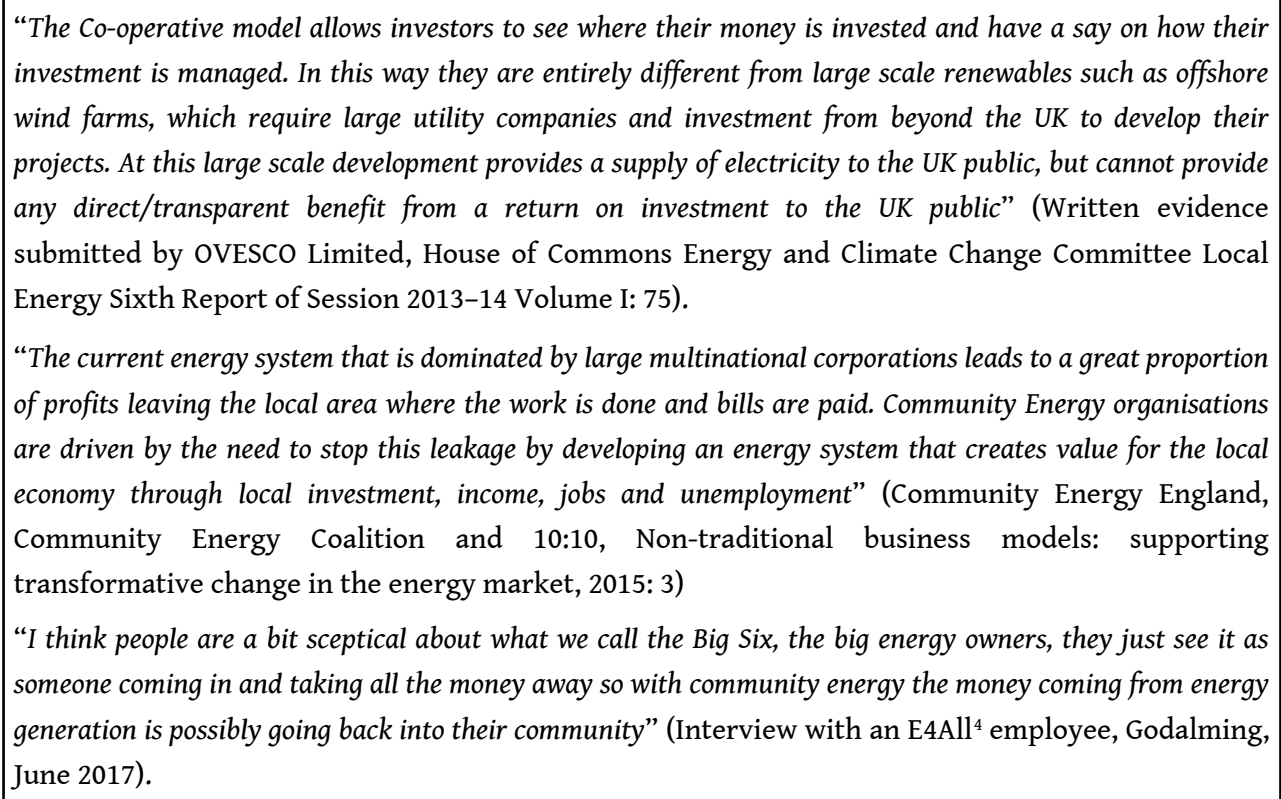


Community energy organisations also present themselves as different from commercial developers by focusing on one practice used by them: community benefits. The latter are "financial packages that make payments directly, or in kind, to local communities" (Kerr, Johnson and Weir, 2017). By promoting collective ownership, community groups want to distinguish themselves from the practice of community benefits:

The Government should promote community ownership as the route to increased community engagement and acceptance. This entails moving away from the notion of 'community benefit' towards community ownership. Community benefits can include varying degrees of financial, environmental and social benefits, often accounting for a tiny fraction of the profit being generated by the development. Community ownership, however, ensures total control and the retention of maximum benefit for the community (...) Community ownership also helps to reassure communities that development is not being foisted on them by large unaccountable energy generators via processes over which they have little control.

(Community Energy Coalition, Manifesto for a community energy revolution, 2014: 15).

By focussing on the issue of control, this extract from a manifesto written by the Community Energy Coalition ${ }^{5}$ refers to a second possibility opened by community energy: a deeper and increased participation of the public within energy projects.

\section{Community energy as a tool for higher public participation in energy development}

18 When it comes to public participation, the alternative dimension of community energy initiatives is twofold: they help to broaden the scope of the role played by citizens and the type of activities developed by energy companies.

While community benefits provided by commercial developers allow the neighbours of energy infrastructures to be local beneficiaries, this approach does not allow them to become project participants or energy producers which is the case with community initiatives. Through a second role, citizens can get involved by becoming members of organising groups, by attending meetings; or by being involved in hands-on installation or maintenance (Walker and Cass, 2007: 465). Through a third role, they can directly own and operate generation technologies (Walker and Cass, 2007: 465). In addition to new roles taken on by citizens, community energy projects also increase also public participation by carrying out activities traditionally not undertaken by public utilities and private suppliers.

20 We already mentioned that one activity done by community energy groups is electricity generation: 157 projects of this type were producing electricity in 2017, mainly photovoltaic energy: $135.6 \mathrm{~mW}$ out of the $168 \mathrm{~mW}$ of community energy in the United Kingdom (30.5 $\mathrm{mW}$ of wind power and $1.47 \mathrm{~mW}$ of hydro power, Community Energy England, State of the Sector Report, 2018). However, community organisations have also pursued two other activities that are not carried out by energy companies involved in the generation market: energy efficiency and fuel poverty alleviation. The former was implemented by 76 organisations in 2017 with different modes of action and participation (Figure 1). 
Figure 1: Energy Efficiency Actions Carried out by 76 Community Energy Groups

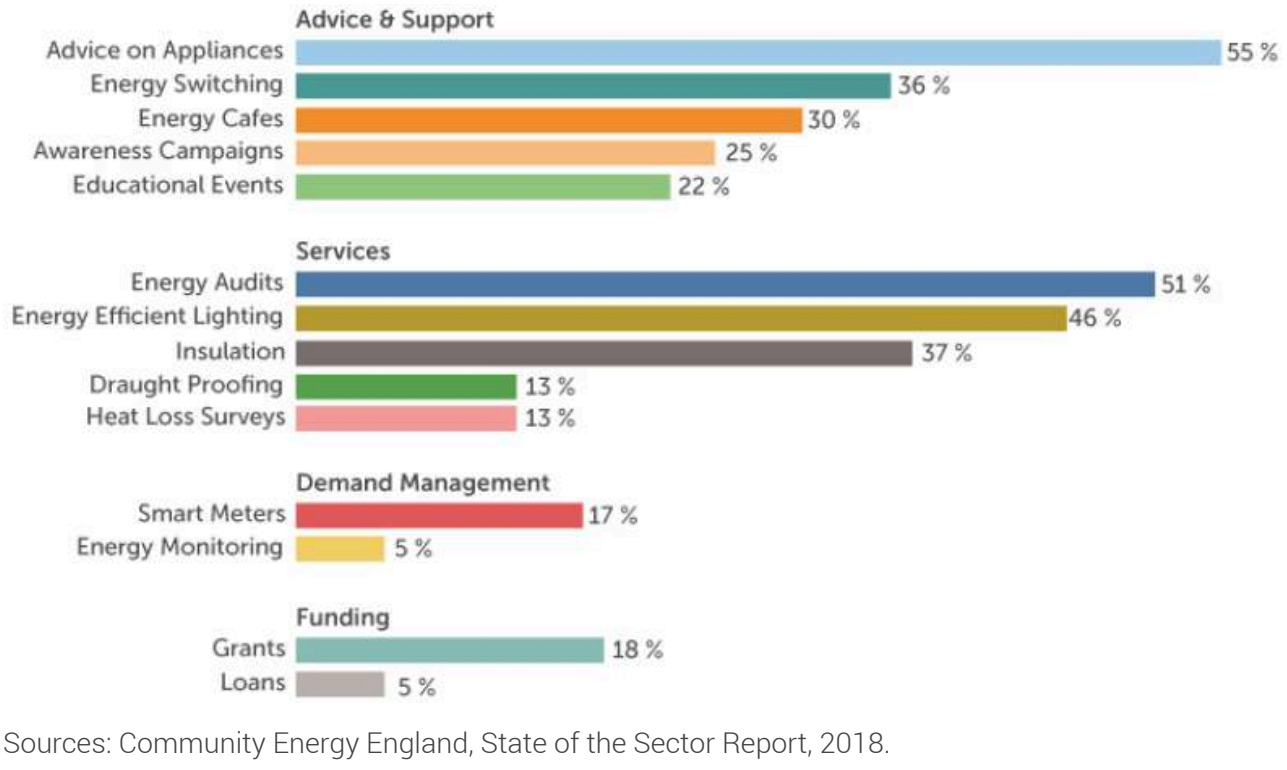

One of these actions increases citizen participation more than the others: the energy café. "Energy Cafés are community-led initiatives providing energy advice in a 'café' or 'shop' setting (...) They have been located in various places, ranging from village halls to libraries and city farms. First and foremost, Energy Cafés provide help for people to understand and manage their energy bills, but they also offer advice on energy efficiency, behavioural measures and renewable energy" (Martiskainen, Heiskanen and Speciale, 2017: 3). One of the three case studies analysed in this article organises such a café: SELCE. The latter describes this type of action in the following terms:

\begin{abstract}
An energy café is a drop-in energy advice service that aims to take away the stigma associated with fuel poverty issues by providing a friendly one-to-one consultation over a cup of tea and a slice of cake. Last winter alone our experienced energy advisors worked with 280 vulnerable residents to identify savings through energy market engagement, access to water or energy discounts, debt write-offs, energysaving tips and accessing grants. The SELCE team attends community events aimed at those who are at risk of fuel poverty. Last winter, we ran 35 workshops attended by 479 people and provided one-to-one advice to 145 clients following these workshops. The total reduction in energy costs for people who took part in the oneto-one advice sessions was £142,163.59 over three years (using conservative assumptions). However, ultimately we aim to provide more tangible benefits in terms of health and wellbeing and give those who are most financially vulnerable a sense of control through understanding how their energy costs relate to their energy use.

(South East London Community Energy, South Share Offer 2019: 18).
\end{abstract}

This form of action is particularly important with regard to the participation of people that are usually not involved in community energy projects like populations with migrant background. According to one employee of SELCE in charge of two energy cafés, this action helps to get in touch and involve this type of population:

For people on low incomes, particularly people who are of colour or of different ethnic background that won't necessarily identify with climate change as an issue, or energy use as an issue because of their identity. You know, I'm an activist, I go along and I go, my identity is all about that... but, you know... It's really different for a mum who's struggling to find enough time to take care of her kids and pay the bills and keep the house, and keep the kid from being a criminal... to keep the kid 
on the straight and narrow. It's really hard for those people. If you want to talk about energy you've got to talk about something that responds to one of their needs. And you know, being able to keep the home warm is where their level of need is. Now, we do talk about climate change, we do talk about energy, when we're doing our fuel poverty alleviation work, but really it's in the context of the needs that they present (...) The starting point has to be something that they feel they need, which is to be able to pay the bill or to keep their home warm.

(Interview with an employee of SELCE, September 2019, London). to the third possibility opened by community energy: higher economic benefit for the local areas.

\section{Community energy as a tool for greater economic benefits in local areas}

Whereas many community energy initiatives are guided by climate change concerns, in many cases community energy is primarily perceived as a tool of local economic development and regeneration (Walker et al, 2007: 73). This dimension is key to explaining why organisations like the National Trust, which are usually not involved in renewable energy development, support community energy initiatives. Accordingly, it was mentioned in a National Trust report published in 2013 that "community renewables schemes can deliver a range of social and economic benefits to local communities including increased autonomy, empowerment and resilience by providing a long term income and local control over finances, often in areas where there are few options for generating wealth" (National Trust, Social and Economic Benefits of Community Energy Schemes, 2013: 2). The fact that community energy can be a tool for local economic development also attracts organisations that tend to be sceptical about renewable energy projects like the Campaign to Protect Rural England:

To many people in the countryside, rural energy conjures up images of big infrastructure and the realities of the high bills that they face. Up until now large power stations, commercially owned renewables, pylons, leaky homes and expensive fuels have contributed to this negative picture. But it doesn't have to be like this. Community energy offers a different way forward where communities are in control, leading and owning projects, and where small can be beautiful. Community energy is not yet commonplace in England, but the Campaign to Protect Rural England (CPRE) and a growing number of organisations and people believe it should be. Rural communities have been at the forefront of this agenda. The essence of community energy is that - whether it is about saving energy through improving the energy efficiency of local buildings or producing renewable electricity or heat locally - it is led and owned by communities. This means that a range of benefits, including financial payback and reduced energy bills, will go directly to all of those within the communities taking them forward. This is particularly important in rural communities where, on average, energy costs are higher and home energy efficiency lower than in urban areas. The vast majority of UK energy projects - mainly generation - are led and owned by large commercial developers. As a result, too often the benefits flow out of the communities.

(Nick Clack presentation, 17 July 2015, Workshop on community energy, Newcastle).

The effects of community energy development on local economies are twofold: direct through reduced energy bills and contracting local installers; indirect through the funding of activities beyond energy projects.

Revue Française de Civilisation Britannique, XXVI-2 | 2021 
Regarding the direct effects, a report on 80 community organisations published by Community Energy England highlights the following elements:

Small-scale community energy projects almost invariably use very local contractors, and this is explicitly part of the aim of many of these organisations. The 38 organisations with existing projects have provided work for 161 local contractors. Of the $£ 50$ million raised for investment in existing projects: $45 \%$ was spent with local businesses ( $£ 23$ million); 43\% was spent with national businesses (£21 million); 12\% was spent with non-UK firms (£6 million). (Community Energy England, Community Energy: Generating more than renewable energy, October 2015: 24).

Regarding the indirect effects, beyond paying dividends to shareholders, community energy projects also use some of the income to support initiatives and infrastructures outside the energy sector, for instance by buying existing infrastructures or creating new ones. The former was done by $14 \%$ of the surveyed community organisations by Community Energy England in 2014, that purchased existing infrastructures to renovate them (e.g. a community hall) or contribute to new ones (e.g. a local shop or pub). In addition to higher public participation and ownership democratisation, these economic benefits contribute to the fact that community energy initiatives in the United Kingdom provide services that make them different from public utilities and private suppliers. However, the second section of this article will show that the transformative power of the alternative model developed by these initiatives is limited because community energy is embedded between the State and the market.

\section{A Limited Transformative Power}

The reality is that all the cooperatives members of Community Energy England are struggling to survive so they stick together as part of this organisation to deal with this vulnerable situation but they can hardly change and influence the market rules because they are too busy struggling to survive and reacting to changes in public policy. (Interview with the Shadow Chancellor's Advisor on Sustainable economics for the Labour Party, London, January 2018).

This extract from an interview with the Shadow Chancellor's Advisor on Sustainable economics for the Labour Party and Member of Parliament for Nottingham South between 1992 and 2010 introduces one of the key elements explaining the limitations encountered by community energy when it comes to constituting an alternative beyond State and market arrangements: the difficulties of the community energy movement to act as rule-makers (Streeck and Thelen, 2005) within the British policy regime. These difficulties are twofold, and concern issues to institutionalise advantages, as well as issues to challenge decisions that have negative effects on their developments.

\section{Community energy organisations: playing the market without ruling it}

This 5 year period was a kind of golden age for community energy because the Energy Department was held by a Lib Dem Ed Davey very supportive of community energy and right now is a chairman of cooperative (...) We were administrating a fund which was meant to be a 10 million fund to help community groups to do early stage technical work, to do feasibility studies and once you knew that your project was feasible we were supposed to be able to borrow a loan of up to $£ 120,000$ to move 
forward to the next steps. But it was very clear as soon as the elections happened that the Conservatives didn't want that to continue and when they won the elections they just cut it (...) The biggest problem was when the new government came in, first they cut the UCEF fund but they also cut the FiT [feed-in-tariff] at the same time and community groups built they financial models based on the revenues coming from the FiT and that amount of money was cut by $83 \%$.

(Interview with a Programme Director at the Centre for Sustainable Energy, Bristol, June 2018) generation of electricity by renewable energy producers, as mentioned by this extract from an interview, the Coalition government from 2010 to 2015 was a golden age for community energy in the United Kingdom. Funding programs like the Urban Community Energy Fund (UCEF) were part of a broader policy framework: the Community Energy Strategy. In addition to UCEF, this strategy included a broad range of working groups: a grid connections working group, a community energy finance roundtable, a shared ownership taskforce, and a community energy contact group. They were meant to tackle the specific issues encountered by community energy initiatives in the United Kingdom. However, as with the UCEF and the decline of the FIT, these working groups have been abolished. These abolitions show that while community energy groups can achieve short term gains, they struggle institutionalising them. These difficulties to institutionalise advantages is key to explaining the difficulties for community energy actors to be rule-makers within the British policy regime. They are related to one key weakness of community energy in the UK: the challenge to build a social movement with collective organisations. "Financial and time resources are important constraints: ${ }^{6}$ simply developing and managing a community energy project is often the main goal of the actors concerned, leaving little scope to lobby government or create networks (...) Although intermediary bodies are emerging, their development has been late and slow. Limited resources also affect their scope to act" (Strachan et al, 2015: 105). An example of these limited resources is evidenced by the staff resources of Community Energy England, the main intermediary organisation for community energy initiatives, with five employees in 2019 , and only one dedicated to lobbying activities. These difficulties are also shown by issues to challenge decisions that have negative effects on their developments.

At the level of the British policy regime as a whole, such constraints are borne out by the unsuccessful challenge of the decline and then removal of the FIT from 2015 onwards. At the level of projects on the ground, these difficulties are shown by the unsuccessful bargaining related to the financial model of Meadows Ozone Energy Services (MOZES). Based on the idea of establishing an Energy Service Company (ESCo) to install solar panels for free on tenants roofs and to tackle fuel poverty within a deprived area of Nottingham, MOZES was created in 2009 by a steering group with different actors. This group was formed with representatives from the Meadows Partnership Trust (MPT), the Nottingham Energy Partnership (NEP), Nottingham City Council and local Residents Associations, a former MP of Nottingham South (Alan Simpson) and National Energy Action (NEA), a national charity undertaking a range of activities to address the causes and treat the symptoms of fuel poverty.

In 2009, MOZES won a $£ 615,000$ grant from the Department of Energy \& Climate Change (DECC) low-carbon communities competition. Following this, the organisation installed 67 photovoltaic systems between February and April 2010. When starting the project, the grant and FiT payments were supposed to be compatible. The income stream 
generated through the payments was planned to be used to install new solar panels and to reduce fuel poverty within the Meadows. However, in May 2011, DECC, based on an interpretation of European Commission State aids ruling (European Commission. State aid N 94/2010, C (2010)2445, JOCE 2010/C 166/02), decided that community energy groups which received grants would not be allowed to receive FiT payments as well. Whereas this decision might be considered as a simple translation of EU legislation, a member of the Meadows board analysed this policy choice as "a restrictive interpretation of EU rules because it is not about market distortion because the MOZES project is not big enough to be market distorter and it is not a commercial enterprise, it's a social enterprise." (Interview with Alan Simpson), Nottingham, January 2018). Some analysts developed similar views about this decision, outlining that "particularly when considered in the context of EC decisions on comparable schemes elsewhere in the EU, it is far from clear that the UK scheme should constitute state aid at the level of FiT generators such as community projects" (Payne and Steeden, 2012; Wokuri and Pechancová, 2018: 38). Assuming that this decision was unfair, MOZES challenged it through three channels of action (Beach and Pedersen, 2013). The first one was the creation of a working group including lawyers and a business-led charity financing community energy projects, Pure Leapfrog. This group was launched to negotiate with DECC civil servants. Through this negotiation, MOZES developed a political work (Smith, 2019) to change the governmental decision with elements highlighting the specificities of community energy and the effects of DECC's decision for MOZES. This working group was not able to influence the decision so then MOZES made bilateral contacts with the Secretary of State in charge within DECC. These bilateral meetings did not modify the decision either, which led MOZES to try a third course of action: publicising the case within parliamentary arenas. This was done through a written question made by a Labour MP from Nottingham in the House of Commons to the Secretary of State for Energy and Climate Change in March 2015. Yet this too failed.

In addition to difficulties institutionalising advantages and challenging policy evolutions that affect negatively the development of community energy, the limited transformative power of this sector in the United Kingdom is also characterised by its corrective role in the provision of services (e.g. fuel poverty alleviation) to mitigate some of the consequences related to the UK's liberalisation of electricity markets.

\section{The action of community energy groups on fuel poverty as an example of their corrective role}

How do you help people manage their fuel debts?

If the problem has to do with energy, then we will help them to apply to a trust fund for debt relief. So British Gas, EDF, E.ON, they all have trust funds where you can apply for debt relief if you're a vulnerable person. Or alternatively it may be that they have built up debt and their repayments are too large. They can't afford the repayment, we might reschedule the payment (...)

And you mentioned the warm home discount ${ }^{7}$. Not all of the energy suppliers do it? No, they don't (...) So for a warm home discount, you have the core group. If you're a pensioner on pension credit, you automatically get it. If you're not, you're part of what's called a board group. Each energy supplier is allowed to define their own board group criteria. So, if you have a low income and you're a pensioner you'll be eligible with one energy provider but not with another. It's really confusing. (Interview with an employee of SELCE, September 2019, London). 
34 As noted in the extract, one way to act on energy bill debts is to apply to a Trust fund to cancel, reduce or reschedule debt. These trusts are managed by big energy suppliers like British Gas or EDF. This design shows that a key avenue to deal with energy debt is closely related to the energy company's willingness to grant a favour towards customers that have set out their deprivation in an application form. Community energy action on debt issues is then very constrained by the power of the main market actors. This constraint and lack of autonomy is also at play for the Warm Home Discount. Through this government scheme introduced in 2011, the access to the discount it is not automatic and it is up to every energy supplier to decide the conditions of eligibility. The transformative power of community energy is here again limited by the fact that, as for the trust application for debt relief, the action on fuel poverty is closely controlled by the energy companies. This limited transformative power of community energy in the UK is finally shown by a third element: the small market share owned by community energy projects.

\section{Community energy in the UK: a small tolerated niche}

"When making comparisons with other European countries it is clear that community renewables are only playing a very small part in helping to secure EU renewable energy and broader climate change targets in the UK" (Strachan et al, 2015: 105) This small part can be captured by looking at the small share of community energy projects in the generation of electricity in the UK. 
Given that the total energy generation capacity across the UK is $97.8 \mathrm{GW}$ (BEIS 2017c), with $38 \mathrm{GW}$ coming from renewables alone (BEIS 2017b), community energy clearly makes up only a very small proportion with 0.19 per cent of total supply. Partly this is because projects involving community ownership are relatively small, both physically and in terms of generation capacity-the mean project capacity size (total capacity/number of projects) amounts to $676 \mathrm{~kW}$. Larger solar projects of up to $9 \mathrm{MW}$ in capacity are emerging, although these are relatively rare. (Willis and Simcock, 2019: 373). "it represented just under $0.4 \%$ of the UK's renewable energy capacity by 2014, supplying the equivalent of only $\sim 65.500$ homes" (Mirzania et al, 2019: 1282). This small share highlights that community energy is a small, tolerated niche between the State and the market rather than a third way likely to replace traditional supplies in the UK.

\section{Conclusion}

With the democratisation of public services through collective ownership, higher public participation in energy development and higher economic benefits for local areas, community energy constitutes a tool for energy democracy with new value propositions (Braunholtz-Speight et al, 2018). The different actions developed to alleviate fuel poverty constitute an example of these innovative value propositions. By opening collective ownership, participation in energy development and economic benefits for local areas, community energy can be characterised as an alternative model to market and State arrangements with significant transformative power. However, this transformative power is limited, due to: i) difficulties for community energy organisations to institutionalise advantages and to challenge adverse policy evolutions within the British policy regime; ii) a corrective role of market failures in the case of fuel poverty; and iii) the small market share owned by community energy projects. These three dimensions underline the way community energy is embedded between the State and the main market actors in the UK. This embeddedness is shown in the difficulties encountered by the collective organisations supporting community energy to act as rule-makers of energy policies and by the fact that the Big Six energy companies remain veto players within the British policy regime (Willis and Simcock, 2018).

\section{BIBLIOGRAPHY}

Becker, Sören and Naumann Matthias Energy Democracy: Mapping the Debate on Energy Alternatives ». Geography Compass, 11, 8. (2017).

Boardman, Brenda, Liberalisation and fuel poverty. Chapter 9 in, Rutledge, Ian and P. Wright (eds.) UK Energy Policy and the End of Market Fundamentalism. (Oxford University Press, Oxford, 2010) pp. 225-280.

Revue Française de Civilisation Britannique, XXVI-2 | 2021 
Boyer, Robert, Économie politique des capitalismes: Théorie de la régulation des crises. (Paris: La Découverte, 2015).

Braunholtz-Speight, Tim., Mander, S., Hannon, Matthew, Hardy, Jeff, McLachlan, Carly., Manderson, Ed., and Sharmina, Maria, The evolution of community energy in the UK. UKERC Working Paper, UK Energy Research Centre (London, 2018).

Burns, Charlotte and Carter, Neil, Brexit and UK Environmental Policy and Politics. Revue Française de Civilisation Britannique, XXIIi(3), 1-18 (2018).

Graham, Stephen and Simon Marvin 'Cherry picking and social dumping: utilities in the 1990s', Utilities Policy, 4 (2), (1994) pp 113-19.

Hall, Peter and Soskice, David, Varieties of capitalism. The institutional foundations of comparative advantage. (Oxford: Oxford University Press, 2001).

Hall, Stephen, Foxon, Timothy J and Bolton Ronan, Financing the civic energy sector: How financial institutions affect ownership models in Germany and the United Kingdom. Energy Research \& Social Science, 12. (2016), pp. 5-15.

Howlett, Michael (dir.), Canadian Forest Policy: Adapting to Change. (Toronto, University of Toronto Press, 2001)

Huybrechts, Benjamin and Haugh, Helen, The Roles of Networks in Institutionalizing New Hybrid Organisational Forms: Insights from the European Renewable Energy Cooperative Network. Organisation Studies, 39(8), (2017),pp 1085-1108.

Kern Florian.; Kuzemko Caroline., Mitchell Catherine., Measuring and explaining policy paradigm change: the case of UK energy policy, Policy \& Politics 42:4 (2014), pp 513-530.

Martiskainen, Mari, Heiskanen Eva, and Speciale Giovanna, Community Energy Initiatives to Alleviate Fuel Poverty: The Material Politics of Energy Cafés. Local Environment 23: (2018), pp 2035.

McAdam Doug and Boudet Hilary, Putting Social Movements in their Place. Explaining Opposition to Energy Projects in the United States, 2000-2005, (Cambridge Studies in Contentious Politics, 2012).

Mirzania, Pegah, Andrews, Deborah, Ford, Andy, Ofori, George and Maidment, Graeme, The Impact of Policy Changes: The Opportunities of Community Renewable Energy Projects in the UK and the Barriers they Face. Energy Policy. 129 (2019), pp. 1282-1296.

Pierson, Paul, "Power in Historical Institutionalism." In The Oxford Handbook of Historical Institutionalism, ed. O. Fioretos, T. G. Falleti and A. Sheingate. (Oxford, UK: Oxford University Press, 2016), pp 124-41.

Smith Andy, « Travail politique et changement institutionnel : une grille d'analyse », Sociologie du travail, Vol. 61 - n 1 (2019).

Snow, David A., Vliegenthart, Rens, Ketelaars, Pauline, The Framing Perspective on Social Movements: Its Conceptual Roots and Architecture. In: David A. Snow, Sarah A. Soule, Hanspeter Kriesi, and Holly J. McCammon. The Wiley Blackwell Companion to Social Movements, New and Updatd Edition, (John Wiley \& Sons Ltd., 2018), pp. 392-411.

Strachan, Peter A., Cowell, Richard., Ellis, Geraint, Sherry-Brennan, Fionnguala, \& Toke, David. (2015). Promoting Community Renewable Energy in a Corporate Energy World. Sustainable Development, 23(2), 96-109

Streeck, Wolfgang and Thelen, Kathleen. A. (Eds.). Beyond Continuity: Institutional Change in Advanced Political Economies. (Oxford: Oxford University Press, 2005). 
Tsebelis, George, Decision Making in Political Systems: Veto Players in Presidentialism, Parliamentarism, Multicameralism and Multipartyism », British Journal of Political Science, 25, 3: (1995), pp 89-325.

Walker Gordon and Cass Noel, Carbon reduction, "the public" and renewable energy: engaging with sociotechnical configurations, Area, 39 (4), (2007) p. 458469.

Walker, Gordon and Devine-Wright, Patrick, Community renewable energy: what should it mean? Energy Policy, 36 (2), (2008), pp. 497-500.

Willis, Rebecca and Simcock, Neil, Consumer (Co-) ownership of renewables in England and Wales (UK). In J. Lowitzsch (Ed.), Energy Transition: Financing Consumer Co-Ownership in Renewables (pp. 369-394) (Palgrave, 2019).

Wokuri Pierre and Pechancová Viera, Islands of innovation in the UK and the Czech Republic Sumpf, P. and Büscher, C. eds., SHAPE ENERGY Research Design Challenge: Control, change and capacity-building in energy systems, (Cambridge, 2018).

Wokuri, Pierre, Participation citoyenne et régimes de politiques publiques : nouvelle donne ou donne inchangée ? Le cas des projets coopératifs d'énergie renouvelable au Danemark et en France. Lien social et Politiques, (82), (2019), 158-180.

\section{NOTES}

1. According to Howlett, "A policy regime can be defined as a persistent and regular political arrangement composed of (1) a set of state-societal relations affecting the style or process of sectoral policy-making; (2) a set of ideas related to governing these interactions and effecting policy contents and instrument choices; and (3) a set of institutions designed to regularise and routinise the content and style of policy-making in the sector concerned", (Howlett, 2001: 7).

2. The micro-brewery, wine and organic farming markets are three examples of this connection (Carroll and Swaminathan, 2000; Swaminathan, 2001; Pozner and Sikavica, 2013).

3. According to many authors, the domination of these six companies is directly related to the privatisation of electricity networks: "The UK's energy market is highly centralised and dominated by large commercial players (Willis and Eyre 2011). This is as a result of the process of privatisation of electricity and gas infrastructure and supply, which until the 1980s was state owned and run. Energy, both heating and electricity, supply is largely dominated by the so-called 'Big Six' companies: British Gas, EDF Energy, E.ON, Npower, Scottish Power, and SSE. Between them, the Big Six supplied nearly 95 per cent of households in 2014" (Willis and Simcock, 2018: 371).

4. Energy4All is a nation-wide network of cooperatives in the United Kingdom initiated in 2002.

5. Initiated in 2011 with the following overall purpose: to "ignite an energy revolution which places communities at its heart and strives for a clean, affordable and secure energy system for all. We are achieving this by helping communities across the UK to own, generate and save energy together" (Community energy coalition website). This coalition includes 43 organisations of different types: environmental NGOs (e.g Friends of the Earth), cooperative networks (e.g. Cooperatives UK) structures specifically dedicated to community energy (e.g. Energy4All) but also organisations beyond the environmental groups (Campaign to Protect Rural England, National Farmers Union, National Trust).

6. These constraints are shown by the low number of community energy organisations having employees and the small number of volunteers involved in these initiatives: " $70 \%$ of organisations were found to have no paid staff and entirely reliant on volunteers to deliver their projects. For groups reliant on volunteers, community energy organisations reported that a small central core of volunteers 
were often responsible for their energy projects. 56\% reported fewer than 10 volunteers" (Community Energy England, State of the Sector report, 2019: 10)

7. It is a $£ 140$ one-off discount on electricity bill during the winter, under the Warm Home Discount Scheme and accessible for two categories of people: the ones receiving the Guarantee Credit element of Pension Credit, known as the "core group" and the ones with low incomes and meeting energy supplier's criteria for the scheme - known as the "broader group" (Ofgem website).

\section{ABSTRACTS}

The British energy policy regime is commonly depicted as large-scale, centrally-planned and private-sector led sector with limited citizen involvement into energy planning and development. However, the number of electricity generation projects owned by community groups has risen dramatically over the last decade. The development of such initiatives raises a key question related to public services provision and market organisation: does community energy constitute an alternative beyond market and State arrangements? Based on semistructured interviews and extensive policy analysis, this article provides a twofold answer to that question. First, it shows that community energy in the United Kingdom constitutes an alternative model to market and State arrangements with the opening of three possibilities: ownership of energy infrastructures by local community groups, participation with higher levels of citizen involvement and economic benefits with profits made from electricity generation distributed within local areas. Second, the article shows that the transformative power of this model is limited because community energy is embedded between the State and the market. This embeddedness is characterised by the fact that community energy organisations struggle to institutionalise advantages and to challenge decisions that affect them negatively, and by a corrective role with a provision of several services that were previously provided by State and market actors.

Le régime de la politique énergétique britannique est généralement décrit comme un secteur centralisé et contrôlé par de grands acteurs de marché avec une participation limitée des citoyens à l'aménagement et au développement énergétiques. Cependant, le nombre de projets de production d'électricité détenu par des collectifs de citoyens et de riverains a considérablement augmenté au cours de la dernière décennie. Le développement de telles initiatives soulève une question clé liée à la fourniture de services publics et à l'organisation des marchés : la community energy constitue-t-elle une alternative aux modes d'organisation socioéconomiques étatiques et marchands? Mobilisant des entretiens semi-directifs et une analyse approfondie des politiques publiques, cet article apporte une double réponse à cette question. Premièrement, il montre que la community energy au Royaume-Uni constitue un modèle alternatif aux modes d'organisation socio-économiques étatiques et marchands avec l'ouverture de trois possibilités : une propriété des infrastructures énergétiques par des groupes de citoyens et de riverains, une plus grande participation citoyenne et enfin une distribution locale des bénéfices de la production d'électricité. Deuxièmement, l'article montre que le pouvoir transformateur de ce modèle est limité car la community energy est encastrée entre l'État et le marché. Cet encastrement se caractérise par le fait que les organisations de soutien à la community energy peinent à institutionnaliser les avantages obtenus et à contester les décisions qui les affectent 
négativement, et par leur rôle compensateur avec la prestation de plusieurs services, auparavant fournis par l'État et les acteurs du marché.

\section{INDEX}

Mots-clés: économie politique, politiques publiques, participation citoyenne, énergies renouvelables, énergie coopérative

Keywords: political economy, public policies, community energy, renewable energy

\section{AUTHOR}

\section{PIERRE WOKURI}

Laboratoire Arènes, Institut d'Etudes Politiques de Rennes.

Pierre Wokuri is a PhD candidate in political science at the Rennes Institute of Political Studies and is a member of the Arènes research centre (UMR 6051). His current areas of research include a comparative analysis of community energy in Denmark, France and the United Kingdom, and the political economy of energy transitions and extractive industries. 